Keynote Review

\title{
IN SILICO REPOSITIONING OF APPROVED DRUGS FOR RARE AND NEGLECTED DISEASES
}

Sean Ekins ${ }^{1,2,3,4}$, Antony J. Williams ${ }^{5}$, Matthew D. Krasowski ${ }^{6}$ and Joel S. Freundlich ${ }^{7}$,

${ }^{1}$ Collaborations in Chemistry, 601 Runnymede Avenue, Jenkintown, PA 19046, U.S.A.

${ }^{2}$ Collaborative Drug Discovery, 1633 Bayshore Highway, Suite 342, Burlingame, CA 94010, U.S.A.

${ }^{3}$ Department of Pharmaceutical Sciences, University of Maryland, MD 21201, U.S.A.

${ }^{4}$ Department of Pharmacology, University of Medicine \& Dentistry of New Jersey (UMDNJ)-Robert Wood Johnson Medical School, 675 Hoes Lane, Piscataway, NJ 08854.

${ }^{5}$ Royal Society of Chemistry, 904 Tamaras Circle, Wake Forest, NC-27587, U.S.A.

${ }^{6}$ Department of Pathology, University of Iowa Hospitals and Clinics, Iowa City, IA, 52242, U.S.A.

${ }^{7}$ Department of Biochemistry and Biophysics, Texas A\&M University, College Station, Texas 77843, U.S.A.

Corresponding Author: Sean Ekins, Collaborations in Chemistry, 601 Runnymede Ave, Jenkintown, PA 19046, Email ekinssean@ yahoo.com, Tel 215-687-1320. 


\section{Teaser Sentence:}

High-throughput screening has found many new uses for FDA approved drugs and research into neglected or rare / orphan diseases can be further accelerated using in silico drug repositioning approaches. 


\begin{abstract}
Neglected and rare diseases traditionally have not been the focus of large pharmaceutical company research as biotech and academia have primarily been involved in drug discovery efforts for such diseases. This area certainly represents a new opportunity as the pharmaceutical industry investigates new markets. One approach to speed up drug discovery is to examine new uses for existing approved drugs; this is termed drug repositioning or drug repurposing and has become increasingly popular in recent years. Analysis of the literature reveals that using high-throughput screening there have been many examples of FDA approved drugs found to be active against additional targets that can be used to therapeutic advantage for repositioning for other diseases. To date there are far fewer such examples where in silico approaches have allowed for the derivation of new uses. It is suggested that with current technologies and databases of chemical compounds (drugs) and related data, as well as close integration with in vitro screening data, improved opportunities for drug repurposing will emerge. In this publication a review of the literature will highlight several proof of principle examples from areas such as finding new inhibitors for drug transporters with 3D pharmacophores and uncovering molecules active against Mycobacterium tuberculosis (Mtb) using Bayesian models of compound libraries. Research into neglected or rare/orphan diseases can likely benefit from in silico drug repositioning approaches and accelerate drug discovery for these diseases.
\end{abstract}




\section{Key words}

Repositioning, repurposing, in silico, neglected disease, rare disease, infectious disease, machine learning, pharmacophore, similarity searching. 


\section{Introduction}

Neglected diseases are tropical infections common in Africa, Asia and the Americas. Infections with Mycobacterium tuberculosis (Mtb) or malaria are often included as neglected diseases and are estimated to kill over two million people annually [1]. Recent studies also suggest that over 2 billion individuals are infected with Mtb alone [2] and this represents approximately one-third of the global population. These statistics highlight the enormous economic and healthcare challenges for the countries and governments affected. There are also thousands of diseases that occur in small patient populations, are not addressed by any treatments [3] and are classed as rare or orphan diseases. Neglected and rare diseases traditionally have not been the focus of big pharmaceutical company research as these diseases have small patient populations in industrialized countries that make it difficult to market drugs that recoup the cost of research and development and then are profitable over the long-term. Consequently, drug discovery for neglected and rare diseases has occurred primarily at biotech companies and in academia in recent years. Traditionally, rare diseases have small patient populations though there is no global agreement on what this size is. In the US it is described as a disease that affects less than 200,000 people. Some estimates suggest this represents over 7000 rare diseases affecting 25-30 million people [4] or 5000 patients per orphan disease with approximately 4000 orphan diseases needing treatment [5]. Clearly such a 'small' market size would make drugs for these diseases less marketable compared with cancers, cardiovascular disease, diabetes, etc. which number in the millions treated annually. However, some have suggested that profits can be made on smaller and smaller patient populations in a personalized medicine strategy and have called for more 
academia-pharma collaborations focused on rare diseases [5]. There are considerable challenges with regards to clinical research applied to rare diseases. Even though over 300 orphan drugs have been approved since the passage of the Orphan Drugs Act in 1983, there is still a long way to go until most diseases have a treatment $[4,5]$.

This situation is changing primarily because pharmaceutical companies may see these rare or neglected diseases as a way to bring in more revenue as well as improve public relations. Developing treatments for rare or orphan diseases may necessitate a smaller investment upfront as, for example, in-licensing deals for an advanced therapeutic candidate targeting this area are usually less costly than the typical $\$ 100$ s of millions for licensing drugs for other diseases [6]. Recently we have seen GlaxoSmithKline (GSK) make some relatively small investments in rare diseases [7], and Pfizer [8] and several other large pharma companies, as well as the World Health Organization have been working together and investing $\$ 150 \mathrm{M}$ on neglected diseases [9]. These efforts may be only the tip of the iceberg, and more substantial investments will follow in the near future to solidify the trend. These investments by pharma for rare diseases are in addition to their significant investments in neglected or tropical diseases represented by the GSK Tres Cantos facility (http://www.gsk.com/collaborations/trescantos.htm), the Novartis Institute for Tropical Diseases in Singapore (http://www.novartis.com/research/nitd/index.shtml), the Lilly MDR-TB Partnership (http://www.lillymdr-tb.com/), the Lilly TB drug discovery initiative (http://www.tbdrugdiscovery.org/) and The Critical Path to TB Drug Regimens (http://www.tballiance.org/cptr/). 
One approach to speeding up drug discovery is to find new uses for existing approved drugs. This is termed drug repositioning or drug repurposing, and traditionally has occurred by serendipity [10]. Another strategy is to look at combinations of approved drugs in the hope of finding synergy [11,12], an approach that has found some success in cancer chemotherapy. In the neglected and rare disease space academic and industry researchers look at repositioning compounds that are already approved for other indications (see references in Table 1 and Table 2). Drug repositioning has been reviewed extensively in the context of finding uses for drugs applied to major diseases such as obesity and Parkinson's disease [10]. Well known examples include thalidomide, sildenafil, bupropion and fluoxetine which found new uses beyond their initially approved therapeutic uses [10]. The example of thalidomide specifically suggests that drugs that were originally withdrawn by manufacturers or removed by the FDA, or other regulatory organizations, may be be resurrected. Thalidomide was notorious for causing birth defects if taken during the first trimester of pregnancy. However, this adverse effect is not a major issue in the novel use of thalidomide in treating multiple myeloma, a disease which is not common in women of child-bearing age.

For pharmaceutical companies, repositioning has significant commercial value as it extends the markets for a compound and finds new uses for shelved compounds at lower financial risk and in a shorter time [13]. There has also been much discussion on how different approaches to repositioning could work but these have not focused specifically on neglected diseases $[10,14]$. Others have proposed that repurposing could be an invaluable tool for neglected diseases [15]. The benefits of repositioning include: working on known druggable targets, the availability of materials and data (such as on 
long term toxicology) that can be used and presented to regulatory authorities and, as a result, the potential for a significantly more time- and cost-effective research and development effort than typically seen with bringing a new drug to market.

In both the major-market and neglected infectious disease realms the rapid emergence of multidrug resistant strains of pathogenic microorganisms would indicate that we need to quickly identify new scaffolds for antibiotics. This likely requires the exploration of chemical space beyond known active antimicrobial compounds. Pharma urgently needs new hits to initiate compound optimization studies. However, productivity of novel antibiotic classes over the last 30-40 years has been extremely low and this is exacerbated by the relatively low hit rates from high-throughput screening (HTS) and secondary screens [16]. There are several new scaffold search efforts that were recently reviewed [17]. For example, Pfizer has shown that pyridopyrimidine compounds derived from a eukaryotic protein kinase inhibitor pharmacophore were effective against gram negative pathogens following whole cell screening [18]. The approach is an example of screening library repurposing (counterbalancing the pessimism derived from recently reported antibacterial-targeted screening efforts [16]) and illustrates the pursuit of bacterial targets with high sequence or structural similarity to eukaryotic targets, in this case the bacterial and eukaryotic kinomes. The Pfizer researchers proposed that targets with high sequence and structural homology to known human drug targets are more likely to find inhibitors in the compound libraries. Others have suggested that the libraries of inhibitors for ion channel and prenyltransferases would be a good starting point for such library repurposing [19] and finding chemotypes for novel antimicrobials. 
It is unclear how extensively approved drugs are screened against multidrug resistant strains of bacteria and it may be possible to find new acceptable treatments amongst them. Clearly, much more could be done to reposition existing approved drugs. The following surveys efforts to find new activities for FDA approved drugs. To date these efforts have traditionally focused on in vitro screening alone but it is proposed that a combined in silico-in vitro approach leveraging databases of molecular structures and their related information from the literature (such as ADME/Tox [20], targets, clinical trials etc.) could be a viable strategy to accelerate research in rare, neglected and major diseases.

\section{Searching FDA approved drugs for new activities}

\section{High-throughput Screening}

It is suggested that there are over 10,000 drugs that have been tested in clinical medicine. This may be reduced to approximately 9,000, given that many represent combinations of other drugs, different salt forms of the same molecule, or biologics (large proteins or antibodies) [21]. However, a physical library of this size does not exist for known drugs that could be screened and a virtual library of these compounds is also lacking. It should be noted that such a virtual library could likely be assembled using some of the public domain databases. Some companies like CEREP (http://www.cerep.fr) have screened 2,500 of the FDA drugs and reference compounds against 159 enzymes, receptors, ion channels and transporters and created a database called BioPrint [22] which is a commercial product with a cost likely out of reach of academic researchers. To date multiple groups have screened 1,000-2,000 drugs against different targets or cell types. 
The John Hopkins Clinical Compound Library (JHCCL) consists of plated compounds available for screening at a relatively small charge and has been used by some groups [23]. For example, 17 novel inhibitors of $M$. tuberculosis were found after screening 1,514 compounds from the JHCCL [23]. Several new uses for FDA approved drugs have been identified by screening this or other commercially available libraries of drugs or offpatent molecules e.g. the Microsource US drug collection and Prestwick Chemical library (Table 2). The accumulation of large databases of published data and compounds screened against G-protein coupled receptors (GPCRs), such as the psychoactive drug screening program (PDSP) receptorome profile, represent good starting points for finding compounds which are active against receptors of interest. One example described is a potent 5- $\mathrm{HT}_{2 \mathrm{~A}}$ ligand that could block the JC virus [24] which can cause the neurologic disease progressive multifocal leukoencephalopathy. A second example suggested side effects for known drugs mediated by the 5- $\mathrm{HT}_{2 \mathrm{~B}}$ receptor [24]. The number of examples of groups finding new uses for approved drugs by HTS appears to be growing (Table 2) on a laboratory by laboratory basis. It is intriguing to ponder whether an organized effort to experimentally screen the set of all known drugs against all known targets validated for a given disease would be feasible. Certainly, the potential for success with one disease, let alone many human diseases, appears to be quite significant.

\section{Computational Methods}

Computational methods, including target- and ligand-based strategies, are an excellent complement to experimental techniques, and are used widely in industry and academia $[25,26]$. There have been many studies establishing relationships between 
ligand molecular structures and broad biological activities, both on and off-target [27-30]. Several examples using pharmacophore-based studies and searching databases of FDA drugs [31] to find new transporter inhibitors in vitro represent attempts at understanding off-target effects. For example, in our previous work we have used pharmacophores for various transporters such as the human peptide transporter 1 (HPEPT1) [32], Pglycoprotein (P-gp) [33], the human organic cation/carnitine transporter (hOCTN2) [34,35] (Figure 1) and the human apical sodium-dependent bile acid transporter (ASBT) [36] to search a subset of FDA approved drugs compiled from a small physician's handbook (SCUT) [31] and to identify previously unknown inhibitors based on in vitro testing (Table 3). What is interesting about this approach is that for each transporter we found inhibitors belonging to different therapeutic classes and obviously these represent molecules with overlapping pharmacophores. What has not been examined to date is whether the distinct therapeutic class hits for a single transporter are also shared by other common biological activities. These transporters were selected because of the inhibition of hPEPT1 or P-gp involved in drug-drug interactions [33]. the putative role of hOCTN2 inhibition in rhabdomyolysis $[34,35]$ and the potential for drugs inhibiting ASBT to promote several adverse drug reactions (ADRs) including colon cancer [36]. The transporters also represent a class of proteins for which in vitro models may be limited in throughput and where in vivo study is even more complicated due to the presence of multiple transporters with overlapping substrate specificities. Therefore, the in silico - in vitro approach has value in targeting testing of compounds with a high probability of activity. 
Pharmacophores and 3D database searching could, in theory, be readily used for repositioning. 2D approaches may, however, be more readily available for both similarity and substructure searching and have been used with success in studies to predict crossreactivity of drugs and drug metabolites with immunoassays utilized in clinical medicine. Common applications of immunoassays include drug of abuse (DOA) screening, endocrinology testing, and therapeutic drug monitoring (TDM). Immunoassays may be limited by the occurrence of false positives (or 'cross-reactive' compounds). For example, drugs with structural similarity to amphetamine and methamphetamine such as ephedrine and pseudoephedrine can cross-react with drug of abuse screening assays designed to detect the presence of amphetamine or methamphetamine. Diagnostic companies manufacturing clinically used immunoassays often test a limited number of compounds for cross-reactivity against their immunoassay while there is a potentially large array of compounds (metabolites, herbals, environmental chemicals) that could possibly interact. Consequently, cross-reacting compounds are discovered on a case-by case basis.

Computational 2D similarity (using the MDL public keys fingerprint descriptors) of test compounds to that of the antigen used in immunoassays, has been used to predict cross reactivity. The same SCUT database of frequently used FDA-approved drugs was used for similarity searching and was supplemented with some metabolites of drugs (see Supplemental data). This relatively simple computational approach showed a statistically significant separation between cross reactive and non cross reactive compounds for TDM immunoassays [37,38] and DOA/toxicology immunoassays [39,40], and was further used 
to identify novel inhibitors of DOA/toxicology immunoassays [40]. These examples show how modeling can build on existing data and focus in vitro testing.

The examples above also illustrate how 2D similarity alone may be useful for finding compounds that may possess similar pharmacophore features to other drugs. This raises the question whether such similar molecules may share overlapping biological activities. Similarity searching could likely be a component of a compound repositioning strategy, using computational methods to predict likely cross reactive compounds by similarity and then quickly confirming with immunoassays that are commercially available. Similarly other computational approaches to searching by similarity, such as those involving LASSO descriptors [41], can make use of large publicly available databases like ChemSpider [42] to compare existing drugs with virtual libraries. Similarly, methods such as PASS (prediction of activity spectrum for substances) could also be used to predict potential new bioactivities for existing drugs [43]. Methods that account for molecular shape may be generally useful for searching for compounds with common bioactivity [44]. Molecular docking is one example that has been successful in finding molecules with complementary shape and electrostatic interactions to known protein active sites. For example, docking approaches have been used to dock 1055 known drugs (from DrugBank) into 78 unique human drug targets and the authors found 52 interactions of interest (although no verification was reported) [45].

\section{Networks and Systems Biology}

In the last decade our understanding of biological mechanisms has been significantly enhanced by the curation of vast ligand and protein-protein interaction 
databases and the use of top-down and bottom-up network modeling leading to a systems biology approach [46-50]. In the past five years alone, 2D-ligand-based approaches have been increasingly used along with sophisticated algorithms and networks. Fliri et al. used biological spectra for a cross section of the proteome [51]. They implemented hierarchical clustering of the biological activity spectra similarity and created a relationship between structure and bioactivity before extending this to identify receptor agonist and antagonist profiles [52]. The same group from Pfizer took this concept further and applied a probabilistic approach to link adverse effects for drugs with biological spectra (similar molecules had overlapping profiles, in the same way that they had similar biological spectra), thus linking preclinical with clinical effects [53]. Such an approach could be useful for repositioning compounds as well as for differentiating compounds that might have some desirable off-target effects, thereby mitigating the undesirable offtarget effects.

There have been many efforts to look at compound or protein promiscuity or polypharmacology. Specifically, there has been considerable discussion of predicting undesirable drug interactions with promiscuous proteins in silico. This is a particular issue for hydrophobic compounds that may bind to cytochrome P450 (CYP) 3A4, the pregnane X receptor (PXR), P-gp or the human ether-a-go-go-related gene (hERG) [54]. Quantitative structure activity relationship (QSAR) models for these proteins have been used to predict potential molecule-protein interactions and then visualize this as a node on a network, simultaneously showing other endogenous and exogenous ligand-protein interactions $[49,50,55]$ as well as allowing overlay of any gene expression or other high content data [56-58]. Such an approach could be useful for ensuring that repurposed 
compounds do not have negative effects on biological networks through binding other off-targets. A global mapping of pharmacological space focusing on a polypharmacology network of 200,000 molecules with activity against 698 proteins has been produced. [59] A further published study created a drug-target network of approved drug data for 890 molecules from DrugBank [60] and OMIM (http://www.ncbi.nlm.nih.gov/omim) with over half of these molecules forming the largest connected network with multiple target proteins (also illustrating polypharmacology or promiscuity) [61]. Such networks might help understand likely nodes involved in toxicity and add to the similarity maps for enzymes and receptors [62] and human polypharmacology networks [59] that have also been developed to date. A recent study from Abbott introduced a sequence-independent kinome inhibitor interaction map [63] while another study established links between over 44,000 small molecules and 160 cardiovascular targets, with kinases having on average 7 connections to cardiovascular targets [64]. An example from Berg et al., has merged chemical target and pathway toxicity mechanisms that can be defined from profiling in primary human cell systems covering many readouts and enabling known reference compounds to be mapped by functional similarity [65].

A complimentary approach taken by a group at Novartis uses chemical substructures relevant for toxicology related adverse effects [66] for approximately 4000 molecules with side-effect information from the World Drug Index. The same group related promiscuity of compounds to their safety [67] as compounds hitting several targets cause more undesired effects. More recently the group has related over 4000 MedDRA [68] terms for ADRs for over 1800 drugs using the ECFP_4 descriptors and Bayesian models [69,70]. This resulted in a map of ADRs in chemical space and an 
approach that could be used to predict, in silico, the ADR likelihood for new molecules based on substructures. Interestingly, the recent similarity ensemble analysis described by Keiser et al. also used the ECFP_4 descriptors and Bayesian models to predict off-target effects of 3665 FDA approved drugs and investigational compounds [71]. This study clearly showed the promiscuity of many compounds. Their in vitro validation of the computational predictions focused on compounds with predicted GPCR activity other than the known targets. The approach may be particularly useful for understanding the potential targets for compounds where these have been previously unknown.

Machine learning models have also been applied with various types of literature data. Decision tree induction has been used to predict the adverse drug reactions for 507 drugs from the Swiss drugs registry, and resulted in models that looked internally predictive [72]. A machine learning method has also been used with a set of 390 drugs to demonstrate that anatomical therapeutic chemical classification, a system used for drug repurposing, can be predicted by using a binary feature vector derived from extraction of drug property data from text alone [73]. Chiang and Butte have compiled a drug-disease knowledge base (DrDKB) to capture the 3,517 FDA approved drug indications and 8,130 off-label uses of 2,022 distinct drugs used to treat each of 726 diseases [74]. They were able to make 57,542 unique novel drug use suggestions and, leaving out 10 to $20 \%$ of the data as a test set, resulted in over $85 \%$ recovery of the drug uses [74]. Others have $\begin{array}{llll}\text { generated } & \text { a } & \text { database } & \text { called }\end{array}$ (http://bioinformatics.charite.de/promiscuous/index.php?site=drugdev) representing a set of 25,000 withdrawn or experimental drugs annotated with 21,500 drug-protein and 104,000 protein-protein relationships, using public resources (e.g. DrugBank, 
SuperTarget, etc.) and text or data mining [75]. These data can be searched using a network visualization tool and several anecdotal examples were provided of molecule or side effect similarity, although no prospective testing was described [75]. Another tool suggested to be useful for drug repositioning is IDMap which integrates the Elsevier MDDR database, Asinex compounds, PASS and molecular descriptors from Cerius ${ }^{2}$ [76]. Text mining was used to compare PASS and MDDR bioactivity and provide a cooccurrence frequency although again, no prospective testing was shown [76]

By connecting data on drugs, proteins and diseases these various databases, network and computational methods may not only be useful for understanding and identifying promiscuity, polypharmacology and toxicity mechanisms, but also potentially for repurposing molecules for new uses that could focus and accelerate in vitro screening efforts $[21,24,77-79]$ as we have previously described with transporters. [32-36]. For some, finding molecules with manageable ADRs may be useful and lead to new indications. Many of these examples illustrate how molecules can be put into a biological context in networks. The integration of approaches and data may lead to a more complete understanding than using a single approach in isolation and could enable network-based drug discovery described elsewhere [80,81]. Others have also suggested that data integration platforms for systems biology (whether using ligand [62,71] or binding site similarity [82]) could support repositioning and drug discovery, although no solid examples of bringing new treatments into the clinic have been provided as yet [83].

\section{Examples specific to infectious diseases}


As a proof of principle that computational methods could accelerate neglected disease research, a machine learning method has been used and validated with multiple datasets. Laplacian-corrected Bayesian classifier models are computationally fast and have been used widely for several drug discovery applications in recent years, including with Mtb [84]. Bayesian classification methods with molecular function class fingerprints of maximum diameter 6 (FCFP_6) [85] have been previously used for CYP, transporter and toxicity models [36,86-89] as well as to identify substructures that are important in recent tuberculosis screening datasets [90]. We have validated the Mtb Bayesian models (training sets from 2000 to $>200,000$ molecules) with external compounds using the published NIAID, GVKbio datasets (which include known drugs and other experimental compounds) and a set of 102,000 compounds (TAACF-NIAID CB2) containing 1702 molecules with $\geq 90 \%$ inhibition at $10 \mu \mathrm{M}$ (representing a hit rate of $1.66 \%$ ) [91]. We were able to show 10 fold enrichments in finding active compounds in the top ranked 600 molecules for the TAACF-NIAID CB2 [91] which came from the same source [90,92] as the training sets used in the original models and represents an ideal scenario from modeling to limit any experimental variability. The 3 test sets ranged from 2880 to over 102,000 compounds. The largest test set also contained a more realistic percentage of hits representative of HTS screens.

More recently we have used a dataset from Novartis of Mtb aerobic assay hits as a test set for the previously described Bayesian models to provide further validation of the approach. Over $35 \%$ of the total hits (minimum inhibitory concentration, MIC, $<10 \mu \mathrm{M}$ ) are found with a Bayesian model in the top $8 \%$ of molecules (enrichment $>4$ fold) [93]. In addition the JHCCL set of 1514 known drugs were screened experimentally against 
Mtb and the MIC values determined using the Alamar blue susceptibility assay (published by others [23]). 21 of the actives identified were used as a test set in a larger set of 2108 FDA approved molecules downloaded from the Collaborative Drug Discovery database (CDD) database. After removal of compounds that were also in the Bayesian models, it was shown that the Bayesian models initially had $\sim 10$ fold enrichments. One model identified $>60 \%$ of the drug hits in the top $14 \%$ of compounds [93] (Figure 2). The Bayesian models were also used to suggest molecules with high probability of predicted Mtb activity that could be tested in vitro in future including: sertaconazole (antifungal), clofarabine (antineoplastic), tioconazole (antifungal) and amodiaquine (antimalarial), quinaldine blue (antineoplastic), atorvastatin (antihyperlipidemic) and montelukast (antiasthmatic) [93].

\section{Resources For In silico Repositioning Of Molecules}

If we are going to try to accelerate rare/orphan and neglected disease research in silico what resources are currently available and what are still needed? One accessible tool is the CDD database [94] with a focus on neglected diseases which has been recently described in detail $[91,95,96]$. Dr. Chris Lipinski (Melior Discovery) provided a database of 1055 FDA approved drugs with designated orphan indications, sponsor name and chemical structures. In addition, Dr. David Sullivan (Johns Hopkins University) collated and provided a database of 2815 FDA approved drugs. Dr. Bryan Roth (University of North Carolina) provided the PDSP database, which currently consists of nearly 1500 molecules structures that have been screened against an array of GPCRs [24,62,78,79]. 
These data, in addition to the $>20$ screening datasets for malaria and tuberculosis (Table 4), have enabled recent analysis of the physicochemical properties of active compounds [91,97,98] and filtering with readily available substructure alerts or "filters" [91,97,98]. All these datasets allow for free access of substructure, similarity or Boolean searches upon registration (e.g., see: http://www.collaborativedrug.com/register). The data has also been used for similarity searching and pharmacophore approaches to find mimics of essential metabolites for Mtb [99].

In addition, a license to CDD can enable download of datasets that are not freely available. This may be advantageous if they need to be searched with third party cheminformatics software, e.g. pharmacophore models or QSAR methods etc (Figure 3). This suggests an additional approach for repurposing using in silico models to find compounds of interest in the FDA approved drugs set. For instance, models generated with data from one or more public datasets (or the users own private data) could be used to search other datasets and find new molecules for screening (Figure 3). This strategy could be readily taken with other databases and software tools taking advantage of freely available content and tools in databases like ChemSpider [42], PubChem [100], DrugBank [60] and ChEMBL [101] or others [20,102,103]. This overall approach is analogous to the pharmacophore approach we have taken with transporters searching the SCUT database of commonly used drugs (Table 3), similarity searching for drugs crossreactive with DOA and TDM immunoassays [37-40] and with Mtb Bayesian models [91,95] for searching the FDA approved drugs. Recent efforts to validate the Bayesian models with data from other laboratories (MRC and Novartis) would indicate that the in silico approach certainly has some merit for neglected diseases. 
What is still needed is a single comprehensive resource that has validated chemical structures (and properties) of both FDA and international approved drugs, as well as those no longer used or removed from the market. A database containing information on studies in which these compounds show activity (e.g. enzyme, receptor, whole cell data, etc.) as well as clinical data would be invaluable. Such a database could then be linked with other mining tools that enable 1D-3D similarity searching. Once created it could be used as the authoritative virtual screening database for repurposing prior to testing physical compounds in whole cells or target assays.

\section{SUMMARY}

Analysis of the literature suggests that using HTS, there have been many examples of FDA approved drugs that are found to be active against additional targets that can be used to therapeutic advantage for repositioning. For example, there are several examples for neglected disease including compounds with antimalarial, anti-tuberculosis, trypanosomal and Chagas disease activity (Table 2). To date there are far fewer such examples where in silico approaches have derived new uses for approved drugs (Table 2) $[82,104]$. However, with current technologies and databases, as well as a close integration with in vitro screening, this will change. Although computational approaches such as ligand- and structure-based methods have been widely used for searching libraries of commercial compounds for neglected diseases [105], few have tried to use already existing drugs with computational methods [82]. A recently described apparent disconnect has been noted in the Mtb community between the generation and utilization 
of computational models for drug discovery [106]. These in silico models are not well disseminated and certainly not used for repositioning FDA approved drugs. This situation needs to be rectified. Another important consideration should be the quality of the structures in the databases used whether of FDA drugs or other molecules, as these will impact the in silico results [102]. If neglected diseases can benefit from in silico methods so can rare or orphan diseases, and of course repositioning approved drugs brings with it other benefits such as 7 years market exclusivity [106]. In our opinion, some or all of the aforementioned in silico approaches should be used alongside other methods to drug repurposing, if for no other reason but to speed up the process of drug discovery at little additional cost.

\section{Acknowledgments}

SE gratefully acknowledges the many groups that have provided datasets including Dr. David Sullivan (Johns Hopkins University). SE kindly acknowledges Dr. Barry A. Bunin and my colleagues at CDD for developing the software and assistance with large datasets and our collaborators. MDK has received support from grant K08-GM074238 from the National Institutes of Health. SE also acknowledges many collaborators including Dr. Maggie A.Z. Hupcey (PA Consulting), Dr. Sandhya Kortagere (Drexel University), Dr. Peter W. Swaan and Dr. James E. Polli (University of Maryland) and their students for collaborations summarized in Table 3. Accelrys are kindly thanked for providing Discovery Studio. 


\title{
Conflicts of Interest
}

SE consults for Collaborative Drug Discovery, Inc on a Bill and Melinda Gates Foundation Grant\#49852 “Collaborative drug discovery for TB through a novel database of SAR data optimized to promote data archiving and sharing”.

Supporting Information Available: Supplemental material is available online. The updated SCUT database is provided as an sd file as used in recent similarity studies and pharmacophore searches [35-37,39,40].

\author{
ABBREVIATIONS \\ ASBT, apical sodium-dependent bile acid transporter; CCR5, Chemokine receptor 5; \\ DHFR, Dihydrofolate reductase; DOA, Drugs of abuse, FDA, Food and Drug \\ Administration; GLT1, Glutamate transporter 1; HSP-90, Heat shock protein 90; hERG, \\ human ether-a-go-go-related gene; hPEPT1, human peptide transporter 1; NK-1, \\ neurokinin- 1 receptor; OCTN2, Organic Cation/Carnitine Transporter; P-gp, P- \\ glycoprotein; PXR, pregnane X receptor; QSAR, quantitative structure activity \\ relationship.
}




\section{References}

1 Fidock, D.A. (2010) Drug discovery: Priming the antimalarial pipeline. Nature 465 (7296), 297-298

2 Balganesh, T.S. et al. (2008) Rising standards for tuberculosis drug development. Trends Pharmacol Sci 29, 576-581

3 http://rarediseases.info.nih.gov/Resources/Rare_Diseases_Information.aspx. (2010)

4 Griggs, R.C. et al. (2009) Clinical research for rare disease: opportunities, challenges, and solutions. Mol Genet Metab 96 (1), 20-26

5 Brewer, G.J. (2009) Drug development for orphan diseases in the context of personalized medicine. Transl Res 154 (6), 314-322

6 http://www.crdnetwork.org/blog/big-pharma-moves-from-blockbusters-to-nichebusters/.

7 http://cenblog.org/the-haystack/2010/10/gsk-highlights-rare-diseases-approach/.

8 http://www.xconomy.com/boston/2010/09/01/pfizer-gobbles-foldrx-in-bigpharmas-latest-rare-disease-play-in-boston-area/.

9 http://thebigredbiotechblog.typepad.com/the-big-red-biotech-blog/2010/10/bigpharma-and-governments-put-up-150-m-to-fight-neglected-diseases.html. 
10 Ashburn, T.T. and Thor, K.B. (2004) Drug repositioning: identifying and developing new uses for existing drugs. Nat Rev Drug Discov 3 (8), 673-683

11 Lehar, J. et al. (2008) High-order combination effects and biological robustness. Mol Syst Biol 4, 215

12 Borisy, A.A. et al. (2003) Systematic discovery of multicomponent therapeutics. Proc Natl Acad Sci U S A 100 (13), 7977-7982

13 Cavalla, D. (2009) APT drug R\&D: the right active ingredient in the right presentation for the right therapeutic use. Nat Rev Drug Discov 8 (11), 849-853

14 Boguski, M.S. et al. (2009) Drug discovery. Repurposing with a difference. Science 324 (5933), 1394-1395

15 Uliana, S.R. and Barcinski, M.A. (2009) Repurposing for neglected diseases. Science 326 (5955), 935; author reply 935

16 Payne, D.A. et al. (2007) Drugs for bad bugs: confronting the challenges of antibacterial discovery. Nat Rev Drug Disc 6, 29-40

17 Fischbach, M.A. and Walsh, C.T. (2009) Antibiotics for emerging pathogens. Science 325 (5944), 1089-1093

18 Miller, J.R. et al. (2009) A class of selective antibacterials derived from a protein kinase inhibitor pharmacophore. Proc Natl Acad Sci U S A 106 (6), 1737-1742 
19 Walsh, C.T. and Fischbach, M.A. (2009) Repurposing libraries of eukaryotic protein kinase inhibitors for antibiotic discovery. Proc Natl Acad Sci U S A 106 (6), $1689-1690$

20 Ekins, S. and Williams, A.J. (2010) Precompetitive Preclinical ADME/Tox Data: Set It Free on The Web to Facilitate Computational Model Building to Assist Drug Development. Lab on a Chip 10,13-22

21 Chong, C.R. and Sullivan, D.J., Jr. (2007) New uses for old drugs. Nature 448 (7154), 645-646

22 Krejsa, C.M. et al. (2003) Predicting ADME properties and side effects: the BioPrint approach. Curr Opin Drug Discov Devel 6 (4), 470-480

23 Lougheed, K.E. et al. (2009) New anti-tuberculosis agents amongst known drugs. Tuberculosis (Edinb) 89 (5), 364-370

24 O'Connor, K.A. and Roth, B.L. (2005) Finding new tricks for old drugs: an efficient route for public-sector drug discovery. Nat Rev Drug Discov 4 (12), $1005-1014$

25 Ekins, S. et al. (2007) In silico pharmacology for drug discovery: methods for virtual ligand screening and profiling. Br J Pharmacol 152, 9-20

26 Ekins, S. et al. (2007) In silico pharmacology for drug discovery: applications to targets and beyond. Br J Pharmacol 152, 21-37 
27 Kauvar, L.M. et al. (1995) Predicting ligand binding to proteins by affinity fingerprinting. Chem Biol 2, 107-118

28 Kauvar, L.M. and Laborde, E. (1998) The diversity challenge in combinatorial chemistry. Curr Opin Drug Disc Dev 1, 66-70

29 Kauvar, L.M. et al. (1998) Protein affinity map of chemical space. $J$ of Chromatography B 715, 93-102

30 Ma'ayan, A. et al. (2007) Network analysis of FDA approved drugs and their targets. Mt Sinai J Med 74 (1), 27-32

31 Gomella, L. and Haist, S. (2004) Clinician's pocket drug reference 2004, McGraw-Hill

32 Ekins, S. et al. (2005) In Vitro And Pharmacophore Based Discovery Of Novel hPEPT1 Inhibitors. Pharm Res 22, 512-517

33 Chang, C. et al. (2006) Rapid Identification of P-glycoprotein Substrates and Inhibitors. Drug Metab Dispos 34, 1976-1984

34 Diao, L. et al. (2010) Quantitative Structure Activity Relationship for Inhibition of Human Organic Cation/Carnitine Transporter. Mol Pharm

35 Diao, L. et al. (2009) Novel Inhibitors of Human Organic Cation/Carnitine Transporter (hOCTN2) via Computational Modeling and In Vitro Testing. Pharm Res 26, 1890-1900 
36 Zheng, X. et al. (2009) Computational models for drug inhibition of the Human Apical Sodium-dependent Bile Acid Transporter. Mol Pharm 6, 1591-1603

37 Krasowski, M.D. et al. (2009) Molecular similarity methods for predicting crossreactivity with therapeutic drug monitoring immunoassays. Ther Drug Monit 31 (3), 337-344

38 Krasowski, M.D. et al. (2010) Immunoassays for tricyclic antidepressants: unsuitable for therapeutic drug monitoring. In Advances in chromatographic techniques for therapeutic drug monitoring (Dasgupta, A., ed.), pp. 179-190, CRC press

39 Krasowski, M.D. et al. (2009) Chemoinformatic methods for predicting interference in drug of abuse/toxicology immunoassays. Clin Chem 55 (6), 12031213

40 Krasowski, M.D. et al. (2009) Using molecular similarity to highlight the challenges of routine immunoassay-based drug of abuse/toxicology screening in emergency medicine. BMC Emerg Med 9, 5

41 Reid, D. et al. (2008) LASSO-ligand activity by surface similarity order: a new tool for ligand based virtual screening. J Comput Aided Mol Des 22 (6-7), 479487

42 Williams, A.J. (2008) Internet-based tools for communication and collaboration in chemistry. Drug Discov Today 13 (11-12), 502-506 
43 Poroikov, V.V.et al. (2000) Robustness of biological activity spectra predicting by computer program PASS for noncongeneric sets of chemical compounds. $J$ Chem Inf Comput Sci 40 (6), 1349-1355

44 Kortagere, S. et al. (2009) The importance of discerning shape in molecular pharmacology. Trends Pharmacol Sci 30 (3), 138-147

45 Li, Y.Y. et al. (2006) A large-scale computational approach to drug repositioning. Genome Inform 17 (2), 239-247

46 Ekins, S. and Abramowitz, D.L. (2007) A systems-biology view of drug transporters. In Transporters as drug carriers (Vol. in press) (Ecker, G. and Chiba, P., eds.), Wiley

47 Ekins, S. and Giroux, C. (2006) Computers and systems biology for Pharmaceutical Research and Development. In Computer Applications in Pharmaceutical Research and Development (Ekins, S., ed.), pp. 139-165, John Wiley and Sons

48 Ekins, S. et al. (2006) Algorithms for network analysis in systems-ADME/Tox using the MetaCore and MetaDrug platforms. Xenobiotica in press

49 Ekins, S. (2006) Systems-ADME/Tox: Resources and network approaches. $J$ Pharmacol Toxicol Methods 53 (1), 38-66 
50 Ekins, S. et al. (2005) Techniques: Application of Systems Biology to Absorption, Distribution, Metabolism, Excretion, and Toxicity. Trends Pharmacol Sci 26, 202-209

51 Fliri, A.F. et al. (2005) Biological spectra analysis: Linking biological activity profiles to molecular structure. Proc Natl Acad Sci U S A 102 (2), 261-266

52 Fliri, A.F. et al. (2005) Biospectra analysis: model proteome characterizations for linking molecular structure and biological response. J Med Chem 48 (22), 69186925

53 Fliri, A.F. et al. (2005) Analysis of drug-induced effect patterns to link structure and side effects of medicines. Nat Chem Biol 1 (7), 389-397

54 Ekins, S. (2004) Predicting undesirable drug interactions with promiscuous proteins in silico. Drug Discovery Today 9, 276-285

55 Ekins, S. et al. (2006) A Combined Approach to Drug Metabolism and Toxicity Assessment. Drug Metab Dispos 34, 495-503

56 Nikolsky, Y. et al. (2005) A novel method for generation of signature networks as biomarkers from complex high throughput data. Tox Lett 158, 20-29

57 Ekins, S. et al. (2005) Systems biology: applications in drug discovery. In Drug discovery handbook (Gad, S., ed.), pp. 123-183, Wiley 
58 Ekins, S. et al. (2007) Pathway mapping tools for analysis of high content data. Methods Mol Biol 356, 319-350

59 Paolini, G.V. et al. (2006) Global mapping of pharmacological space. Nat Biotechnol 24 (7), 805-815

60 Wishart, D.S. et al. (2008) DrugBank: a knowledgebase for drugs, drug actions and drug targets. Nucleic Acids Res 36 (Database issue), D901-906

61 Yildirim, M.A. et al. (2007) Drug-target network. Nat Biotechnol 25 (10), 11191126

62 Keiser, M.J. et al. (2007) Relating protein pharmacology by ligand chemistry. Nat Biotechnol 25 (2), 197-206

63 Metz, J.T. and Hajduk, P.J. (2010) Rational approaches to targeted polypharmacology: creating and navigating protein-ligand interaction networks. Curr Opin Chem Biol 14 (4), 498-504

64 Cases, M. and Mestres, J. (2009) A chemogenomic approach to drug discovery: focus on cardiovascular diseases. Drug Discov Today 14 (9-10), 479-485

65 Berg, E.L. et al. (2010) Chemical target and pathway toxicity mechanisms defined in primary human cell systems J Pharmacol Toxicol Methods 61, 3-15 
66 Bender, A. et al. (2007) Analysis of Pharmacology Data and the Prediction of Adverse Drug Reactions and Off-Target Effects from Chemical Structure. ChemMedChem 2 (6), 861-873

67 Azzaoui, K. et al. (2007) Modeling Promiscuity Based on in vitro Safety Pharmacology Profiling Data. ChemMedChem 2 (6), 874-880

68 (2008) MedDRA MSSO. MedDRA - The medical dictionary for regulatory activities

69 Scheiber, J. et al. (2009) Gaining insight into off-target mediated effects of drug candidates with a comprehensive systems chemical biology analysis. J Chem Inf Model 49 (2), 308-317

70 Scheiber, J. et al. (2009) Mapping adverse drug reactions in chemical space. $J$ Med Chem 52 (9), 3103-3107

71 Keiser, M.J. et al. (2009) Predicting new molecular targets for known drugs. Nature 462 (7270), 175-181

72 Hammann, F. et al. (2010) Prediction of adverse drug reactions using decision tree modeling. Clin Pharmacol Ther 88 (1), 52-59

73 Gurulingappa, H. et al. (2009) Concept-based semi-automatic classification of drugs. J Chem Inf Model 49 (8), 1986-1992 
74 Chiang, A.P. and Butte, A.J. (2009) Systematic evaluation of drug-disease relationships to identify leads for novel drug uses. Clin Pharmacol Ther 86 (5), $507-510$

75 von Eichborn, J. et al. (2010) PROMISCUOUS: a database for network-based drug-repositioning. Nucleic Acids Res

76 Ha, S. et al. (2008) IDMap: facilitating the detection of potential leads with therapeutic targets. Bioinformatics 24 (11), 1413-1415

77 Jensen, N.H. and Roth, B.L. (2008) Massively parallel screening of the receptorome. Comb Chem High Throughput Screen 11 (6), 420-426

78 Strachan, R.T. et al. (2006) Screening the receptorome: an efficient approach for drug discovery and target validation. Drug Discov Today 11 (15-16), 708-716

79 Roth, B.L. et al. (2004) Screening the receptorome to discover the molecular targets for plant-derived psychoactive compounds: a novel approach for CNS drug discovery. Pharmacol Ther 102 (2), 99-110

80 Schadt, E.E. et al. (2009) A network view of disease and compound screening. Nat Rev Drug Discov 8 (4), 286-295

81 Pujol, A. et al. (2010) Unveiling the role of network and systems biology in drug discovery. Trends Pharmacol Sci 31 (3), 115-123 
82 Kinnings, S.L. et al. (2009) Drug discovery using chemical systems biology: repositioning the safe medicine Comtan to treat multi-drug and extensively drug resistant tuberculosis. PLoS Comput Biol 5 (7), e1000423

83 Cockell, S.J. et al. (2010) An integrated dataset for in silico drug discovery. $J$ Integr Bioinform 7 (3)

84 Prathipati, P. et al. (2008) Global Bayesian models for the prioritization of antitubercular agents. J Chem Inf Model 48 (12), 2362-2370

85 Jones, D.R. et al. (2007) Computational approaches that predict metabolic intermediate complex formation with CYP3A4 (+b5). Drug Metab Dispos 35 (9), $1466-1475$

86 Zientek, M. et al. (2010) Integrated in silico-in vitro strategy for addressing cytochrome P450 3A4 time-dependent inhibition. Chem Res Toxicol 23 (3), 664676

87 Pan, Y. et al. (2010) Identification and Validation of Novel hPXR Activators Amongst Prescribed Drugs via Ligand-Based Virtual Screening. Drug Metab Dispos

88 Ekins, S. et al. (2010) A Predictive Ligand-Based Bayesian Model for Human Drug Induced Liver Injury. Drug Metab Dispos 38, 2302-2308 
89 Ekins, S. et al. (2009) Challenges Predicting Ligand-Receptor Interactions of Promiscuous Proteins: The Nuclear Receptor PXR. PLoS Comput Biol 5, e1000594

90 Ananthan, S. et al. (2009) High-throughput screening for inhibitors of Mycobacterium tuberculosis H37Rv. Tuberculosis (Edinb) 89, 334-353

91 Ekins, S. et al. (2010) Analysis and hit filtering of a very large library of compounds screened against Mycobacterium tuberculosis Mol BioSyst 6, 23162324

92 Maddry, J.A. et al. (2009) Antituberculosis activity of the molecular libraries screening center network library. Tuberculosis (Edinb) 89, 354-363

93 Ekins, S. and Freundlich, J.S. (2010) Validating new tuberculosis computational models with public whole cell screening aerobic activity datasets Submitted

94 Hohman, M. et al. (2009) Novel web-based tools combining chemistry informatics, biology and social networks for drug discovery. Drug Disc Today 14, 261-270

95 Ekins, S. et al. (2010) A Collaborative Database And Computational Models For Tuberculosis Drug Discovery. Mol BioSystems 6, 840-851

96 Ekins, S. et al. (2010) Pioneering use of the cloud for development of the collaborative drug discovery (cdd) database In Collaborative Computational 
Technologies for Biomedical Research (Vol. in press) (Ekins, S. et al., eds.), Wiley and Sons

97 Ekins, S. and Williams, A.J. (2010) Meta-analysis of molecular property patterns and filtering of public datasets of antimalarial "hits" and drugs. MedChemComm In press

98 Ekins, S. and Williams, A.J. (2010) When Pharmaceutical Companies Publish Large Datasets: An Abundance Of Riches Or Fool's Gold? Drug Disc Today 15, $812-815$

99 Lamichhane, G. et al. (2010) Essential Metabolites of M. tuberculosis and their Mimics. Mbio in press

100 Wang, Y. et al. (2010) An overview of the PubChem BioAssay resource. Nucleic Acids Res 38 (Database issue), D255-266

101 ChEMBL Database.

102 Williams, A.J. et al. (2009) Free Online Resources Enabling Crowdsourced Drug Discovery. Drug Discovery World 10, Winter, 33-38

103 Louise-May, S. et al. (2009) Towards integrated web-based tools in drug discovery. Touch Briefings - Drug Discovery 6, 17-21

104 Bisson, W.H. et al. (2007) Discovery of antiandrogen activity of nonsteroidal scaffolds of marketed drugs. Proc Natl Acad Sci U S A 104 (29), 11927-11932 
105 Jenwitheesuk, E. et al. (2008) Novel paradigms for drug discovery: computational multitarget screening. Trends Pharmacol Sci 29 (2), 62-71

106 Ekins, S. et al. (2010) Computational Databases, Pathway and Cheminformatics Tools for Tuberculosis Drug Discovery. Trends in Microbiology In Press

107 Manak, M.M. et al. (2010) Anti-HIV-1 activity of the neurokinin-1 receptor antagonist aprepitant and synergistic interactions with other antiretrovirals. Aids 24 (18), 2789-2796

108 Wang, X. et al. (2007) Neurokinin-1 receptor antagonist (aprepitant) inhibits drug-resistant HIV-1 infection of macrophages in vitro. J Neuroimmune Pharmacol 2 (1), 42-48

109 Robinson, P. et al. (2008) Substance P receptor antagonism for treatment of cryptosporidiosis in immunosuppressed mice. J Parasitol 94 (5), 1150-1154

110 Oldfield, E. (2010) Targeting isoprenoid biosynthesis for drug discovery: bench to bedside. Acc Chem Res 43 (9), 1216-1226

111 Ting, H.J. and Khasawneh, F.T. (2010) Glybenclamide: an antidiabetic with in vivo antithrombotic activity. Eur J Pharmacol 649 (1-3), 249-254

112 Miguel, D.C. et al. (2008) Tamoxifen is effective in the treatment of Leishmania amazonensis infections in mice. PLoS Negl Trop Dis 2 (6), e249 
113 Miguel, D.C. et al. (2007) Tamoxifen is effective against Leishmania and induces a rapid alkalinization of parasitophorous vacuoles harbouring Leishmania (Leishmania) amazonensis amastigotes. J Antimicrob Chemother 60 (3), 526-534

114 Senkovich, O. et al. (2005) Lipophilic antifolate trimetrexate is a potent inhibitor of Trypanosoma cruzi: prospect for chemotherapy of Chagas' disease. Antimicrob Agents Chemother 49 (8), 3234-3238

115 Namkoong, J. et al. (2007) Metabotropic glutamate receptor 1 and glutamate signaling in human melanoma. Cancer Res 67 (5), 2298-2305

116 Peng, Q. et al. (2008) The antidepressant sertraline improves the phenotype, promotes neurogenesis and increases BDNF levels in the R6/2 Huntington's disease mouse model. Exp Neurol 210 (1), 154-163

117 Chong, C.R. et al. (2007) Inhibition of angiogenesis by the antifungal drug itraconazole. ACS Chem Biol 2 (4), 263-270

118 Chong, C.R. et al. (2006) A clinical drug library screen identifies astemizole as an antimalarial agent. Nat Chem Biol 2 (8), 415-416

119 Chong, C.R. et al. (2006) Identification of type 1 inosine monophosphate dehydrogenase as an antiangiogenic drug target. J Med Chem 49 (9), 2677-2680

120 de Carvalho, L.P. et al. (2009) Nitazoxanide kills replicating and nonreplicating Mycobacterium tuberculosis and evades resistance. J Med Chem 52 (19), 57895792 
121 Shahinas, D. et al. (2010) A repurposing strategy identifies novel synergistic inhibitors of Plasmodium falciparum heat shock protein 90. J Med Chem 53 (9), $3552-3557$

122 Chopra, S. et al. (2010) Repurposing FDA-approved drugs to combat drugresistant Acinetobacter baumannii. J Antimicrob Chemother 65 (12), 2598-2601

123 Miller, S.C. et al. (2010) Identification of known drugs that act as inhibitors of NF-kappaB signaling and their mechanism of action. Biochem Pharmacol 79 (9), $1272-1280$

124 Downey, A.S. et al. (2008) Efficacy of pyrvinium pamoate against Cryptosporidium parvum infection in vitro and in a neonatal mouse model. Antimicrob Agents Chemother 52 (9), 3106-3112

125 Mackey, Z.B. et al. (2006) Discovery of trypanocidal compounds by whole cell HTS of Trypanosoma brucei. Chem Biol Drug Des 67 (5), 355-363

126 Biechele, T.L. et al. (2010) Chemical-Genetic Screen Identifies Riluzole as an Enhancer of Wnt/beta-catenin Signaling in Melanoma. Chem Biol 17 (11), 11771182

127 Gloeckner, C. et al. (2010) Repositioning of an existing drug for the neglected tropical disease Onchocerciasis. Proc Natl Acad Sci U S A 107 (8), 3424-3429

128 Shim, J.S. et al. (2010) Effect of nitroxoline on angiogenesis and growth of human bladder cancer. J Natl Cancer Inst 
129 Zhang, Y. et al. (2009) Identification of inhibitors of ABCG2 by a bioluminescence imaging-based high-throughput assay. Cancer Res 69 (14), $5867-5875$

130 Masuda, N. et al. (2008) Tiagabine is neuroprotective in the N171-82Q and R6/2 mouse models of Huntington's disease. Neurobiol Dis 30 (3), 293-302

131 Zhang, H. et al. (2008) Digoxin and other cardiac glycosides inhibit HIF-1alpha synthesis and block tumor growth. Proc Natl Acad Sci U S A 105 (50), 1957919586

132 Ou, H.C. et al. (2009) Identification of FDA-approved drugs and bioactives that protect hair cells in the zebrafish (Danio rerio) lateral line and mouse (Mus musculus) utricle. J Assoc Res Otolaryngol 10 (2), 191-203

133 Peterson, S.A. et al. (1998) Inhibiting transthyretin conformational changes that lead to amyloid fibril formation. Proc Natl Acad Sci U S A 95 (22), 12956-12960

134 Ekins, S. (2009) Drug transporter pharmacophores. In Transporters as drug carriers: structure,function, substrates (Vol. 44) (Ecker, G. and Chiba, P., eds.), pp. 215-227, Wiley-VCH Verlag GmbH \& Co KGaA

135 Guiguemde, W.A. et al. (2010) Chemical genetics of Plasmodium falciparum. Nature 465 (7296), 311-315

136 Gamo, F.-J. et al. (2010) Thousands of chemical starting points for antimalarial lead identification. Nature 465, 305-310 
Table 1. Approved drug molecules identified with new uses against other diseases other than originally intended using low throughput methods.

\begin{tabular}{|c|c|c|c|c|}
\hline Molecule & Original use & New use & How discovered & Ref \\
\hline Aprepitant & $\begin{array}{l}\text { Nausea }- \text { NK-1 } \\
\text { receptor antagonist }\end{array}$ & $\begin{array}{l}\text { Drug resistant HIV- } \\
1 \text { Infection } \\
\text { downregulates } \\
\text { CCR5 in } \\
\text { macrophages. }\end{array}$ & $\begin{array}{l}\text { Initial hypothesis } \\
\text { tested with another } \\
\text { NK-1 receptor } \\
\text { antagonist in vitro. }\end{array}$ & $\begin{array}{l}{[107,} \\
108]\end{array}$ \\
\hline Aprepitant & $\begin{array}{l}\text { Nausea }- \text { NK-1 } \\
\text { receptor antagonist }\end{array}$ & $\begin{array}{l}\text { Cryptosporidiosis } \\
\text { in } \\
\text { immunosuppressed } \\
\text { hosts. }\end{array}$ & $\begin{array}{l}\text { Tested in vivo in } \\
\text { immunosuppressed } \\
\text { mice infected with } \\
\text { Cryptosporidium } \\
\text { parvum - } \\
\text { decreased } \\
\text { substance P levels. }\end{array}$ & [109] \\
\hline Amiodarone & $\begin{array}{l}\text { Class III anti- } \\
\text { arrhythmic }\end{array}$ & $\begin{array}{l}\text { Chagas Disease } \\
\text { blocks ergosterol } \\
\text { biosynthesis. }\end{array}$ & Literature search. & [110] \\
\hline Glybenclamide & Antidiabetic & $\begin{array}{l}\text { Antithrombotic } \\
\text { activity in mouse } \\
\text { models } \text { IC }_{50} 9.6 \mu \mathrm{M} \text {. }\end{array}$ & $\begin{array}{l}\text { Common } \\
\text { pharmacophore } \\
\text { with an }\end{array}$ & [111] \\
\hline
\end{tabular}




\begin{tabular}{|c|c|c|c|c|}
\hline & & & $\begin{array}{l}\text { experimental TP } \\
\text { receptor antagonist } \\
\text { SQ29,548. }\end{array}$ & \\
\hline Tamoxifen & Antiestrogen & $\begin{array}{l}\text { Anti-protozoal- } \\
\text { Leishmania } \\
\text { amazonensis } \mathrm{IC}_{50} \\
11.1-16.4 \mu \mathrm{M} \text {. }\end{array}$ & $\begin{array}{l}\text { Focused screening } \\
\text { to test hypothesis } \\
\text { and in vivo mice } \\
\text { studies. }\end{array}$ & $\begin{array}{l}{[112,} \\
113]\end{array}$ \\
\hline Trimetrexate & $\begin{array}{l}\text { Anti folate used in } \\
\text { Pneumocystis } \\
\text { carinii infection in } \\
\text { AIDS patients }\end{array}$ & $\begin{array}{l}\text { Inhibitor of T. cruzi } \\
\text { Dihydrofolate } \\
\text { reductase (DHFR) } \\
\text { IC }_{50} 6.6 \mathrm{nM} \text {. }\end{array}$ & $\begin{array}{l}\text { Enzyme activity } \\
\text { and antiparasite } \\
\text { activity assays for } \\
\text { one compound. }\end{array}$ & [114] \\
\hline Riluzole & $\begin{array}{l}\text { Amyotrophic } \\
\text { Lateral Sclerosis - } \\
\text { inhibits glutamate } \\
\text { release and } \\
\text { reuptake }\end{array}$ & $\begin{array}{l}\text { Riluzole is in } \\
\text { clinical trials for } \\
\text { melanoma but may } \\
\text { have activity } \\
\text { against other } \\
\text { cancers. }\end{array}$ & $\begin{array}{l}\text { Riluzole treatment } \\
\text { of GRM1-positive } \\
\text { human melanoma } \\
\text { cells reduced } \\
\text { levels of released } \\
\text { glutamate, } \\
\text { suppressed human } \\
\text { melanoma cell } \\
\text { growth and also } \\
\text { suppressed tumor } \\
\text { growth in } \\
\text { xenograft model. }\end{array}$ & [115] \\
\hline
\end{tabular}




\begin{tabular}{|l|l|l|l|l|}
\hline & & & induced cell cycle & \\
& & & arrest leading to & \\
\hline Sertraline & Antidepressant & Neuroprotective, & Previously shown & {$[116]$} \\
& reuptake inhibitor) & improves motor & was & that another SSRI \\
& performance and & neuroprotective. & \\
& ameliorates brain & & \\
& & atrophy in the R6/2 & & \\
& & HD model. & & \\
\hline
\end{tabular}


Table 2. Approved drug molecules identified with new uses against other diseases other than originally intended using HTS or in silico methods.

\begin{tabular}{|c|c|c|c|c|}
\hline Molecule & \begin{tabular}{|l} 
Original use \\
\end{tabular} & New use & How discovered & Ref \\
\hline Itraconazole & $\begin{array}{l}\text { Antifungal - } \\
\text { lanosterol } 14 \alpha- \\
\text { demethylase } \\
\text { inhibitor }\end{array}$ & $\begin{array}{l}\text { Inhibition of } \\
\text { angiogenesis by } \\
\text { inhibiting human } \\
\text { lanosterol } 14 \alpha- \\
\text { demethylase IC } 50 \\
\text { 160nM. }\end{array}$ & $\begin{array}{l}\text { In vitro HUVEC } \\
\text { proliferation } \\
\text { screen against } \\
\text { FDA approved } \\
\text { drugs (JHCCL) }\end{array}$ & [117] \\
\hline Astemizole & $\begin{array}{l}\text { Non-sedating } \\
\text { antihistamine } \\
\text { (removed from } \\
\text { USA market by } \\
\text { FDA in 1999) }\end{array}$ & $\begin{array}{l}\text { Antimalarial } \mathrm{IC}_{50} \\
227 \mathrm{nM} \text { against } P \text {. } \\
\text { falciparum 3D7. }\end{array}$ & $\begin{array}{l}\text { In vitro screen for } \\
\text { P. Falciparum } \\
\text { growth of } 1937 \\
\text { FDA approved } \\
\text { drugs (JHCCL) }\end{array}$ & {$[118]$} \\
\hline $\begin{array}{l}\text { Mycophenolic } \\
\text { acid }\end{array}$ & $\begin{array}{l}\text { Immunosuppresive } \\
\text { drug inhibits } \\
\text { guanine nucleotide } \\
\text { biosynthesis }\end{array}$ & $\begin{array}{l}\text { Inhibition of } \\
\text { angiogenesis by } \\
\text { targeting Type } 1 \\
\text { inosine } \\
\text { monophosphate } \\
\text { dehydrogenase } \mathrm{IC}_{50} \\
\text { 99.2nM. }\end{array}$ & $\begin{array}{l}\text { In vitro HUVEC } \\
\text { proliferation } \\
\text { screen } 2450 \mathrm{FDA} \\
\text { and foreign } \\
\text { approved drugs } \\
(\mathrm{JHCCL})\end{array}$ & [119] \\
\hline Entacapone and & Parkinson's Disease & Anti-tuberculosis - & Used a chemical & [82] \\
\hline
\end{tabular}




\begin{tabular}{|c|c|c|c|c|}
\hline Tolcapone & $\begin{array}{l}\text { - Catechol-O- } \\
\text { methyltransferase } \\
\text { inhibitors }\end{array}$ & $\begin{array}{l}\text { Entacapone inhibits } \\
\text { InhA IC }_{50} 80 \mu \mathrm{M} \text {. }\end{array}$ & $\begin{array}{l}\text { systems biology } \\
\text { approach }\end{array}$ & \\
\hline Nitazoxanide & $\begin{array}{l}\text { Infections caused } \\
\text { by Giarda and } \\
\text { cryptosproridium }\end{array}$ & $\begin{array}{l}\text { Anti-tuberculosis - } \\
\text { multiple potential } \\
\text { targets. }\end{array}$ & $\begin{array}{l}\text { Screens against } \\
\text { replicating and non } \\
\text { replicating M. } \\
\text { tuberculosis }\end{array}$ & [120] \\
\hline $\begin{array}{l}\text { ( } \pm \text { )-2-amino-3- } \\
\text { phosphonopropio } \\
\text { nic acid }\end{array}$ & $\begin{array}{l}\text { Human metabolite, } \\
\text { mGLUR agonist }\end{array}$ & $\begin{array}{l}\text { Antimalarial }- \\
\text { Inhibits HSP90 } \mathrm{IC}_{50} \\
0.06 \mu \mathrm{M} \text { against } P \text {. } \\
\text { falciparum 3D7. }\end{array}$ & $\begin{array}{l}\text { HTS screening } \\
4000 \text { compounds }\end{array}$ & [121] \\
\hline Acrisorcin & Antifungal & $\begin{array}{l}\text { Antimalarial }- \\
\text { Inhibits HSP90 } \mathrm{IC}_{50} \\
0.05 \mu \mathrm{M} \text { against } P . \\
\text { falciparum 3D7. }\end{array}$ & $\begin{array}{l}\text { HTS screening } \\
4000 \text { compounds }\end{array}$ & \begin{tabular}{|l}
{$[121]$} \\
\end{tabular} \\
\hline Harmine & Anticancer & $\begin{array}{l}\text { Antimalarial }- \\
\text { Inhibits HSP90 } \mathrm{IC}_{50} \\
0.05 \mu \mathrm{M} \text { against } P . \\
\text { falciparum 3D7. }\end{array}$ & $\begin{array}{l}\text { HTS screening } \\
4000 \text { compounds }\end{array}$ & [121] \\
\hline $\begin{array}{l}\text { Acetophenazine, } \\
\text { Fluphenazine, } \\
\text { Periciazine }\end{array}$ & $\begin{array}{l}\text { Antipsychotics - } \\
\mathrm{D} 2 \text { and 5-HT } 2 \\
\text { inhibitors }\end{array}$ & $\begin{array}{l}\text { Human androgen } \\
\text { receptor antagonists } \\
\text { acetophenazine }\left(\mathrm{K}_{\mathrm{i}}\right. \\
0.8 \mu \mathrm{M}) \text {, }\end{array}$ & $\begin{array}{l}\text { Docking of known } \\
\text { drugs into } \\
\text { Androgen receptor } \\
\text { followed by in }\end{array}$ & [104] \\
\hline
\end{tabular}




\begin{tabular}{|c|c|c|c|c|}
\hline & & $\begin{array}{l}\text { fluphenazine }\left(K_{i} 0.8\right. \\
\mu \mathrm{M}) \text {, periciazine } \\
\left(\mathrm{K}_{\mathrm{i}} 3.0 \mu \mathrm{M}\right) .\end{array}$ & vitro screening & \\
\hline $\begin{array}{l}\text { Levofloxacin, } \\
\text { Gatifloxacin, } \\
\text { Sarafloxacin, } \\
\text { Moxifloxacin, } \\
\text { Gemifloxacin }\end{array}$ & DNA gyrase & $\begin{array}{l}\text { Active against } \\
\text { ATCC } 17978 \\
\text { inactive against } \\
\text { BAA-1605 MIC } \\
<0.03-0.04 \\
(\mathrm{mg} / \mathrm{L})\end{array}$ & $\begin{array}{l}\text { Screened } \\
\text { microsource drugs } \\
\text { libarary of } 1040 \\
\text { drugs versus } A \text {. } \\
\text { baumannii }\end{array}$ & [122] \\
\hline $\begin{array}{l}\text { Bithional, } \\
\text { Bortezomib, } \\
\text { Cantharidin, } \\
\text { Chromomycin } \\
\text { A3, } \\
\text { Duanorubicin, } \\
\text { Digitoxin, } \\
\text { Ectinascidin 743, } \\
\text { Emetine, } \\
\text { Fluorosalen, } \\
\text { Manidipine HCl, } \\
\text { Narasin, } \\
\text { Lestaurtinib, } \\
\text { Ouabain, }\end{array}$ & Various & $\begin{array}{l}\text { NF-кB inhibitors } \\
\text { IC }_{50} 0.02-39.8 \mu \mathrm{M}\end{array}$ & $\begin{array}{l}\text { Screened NCGC } \\
\text { pharmaceutical } \\
\text { collection of } 2816 \\
\text { small molecules in } \\
\text { vitro }\end{array}$ & [123] \\
\hline
\end{tabular}




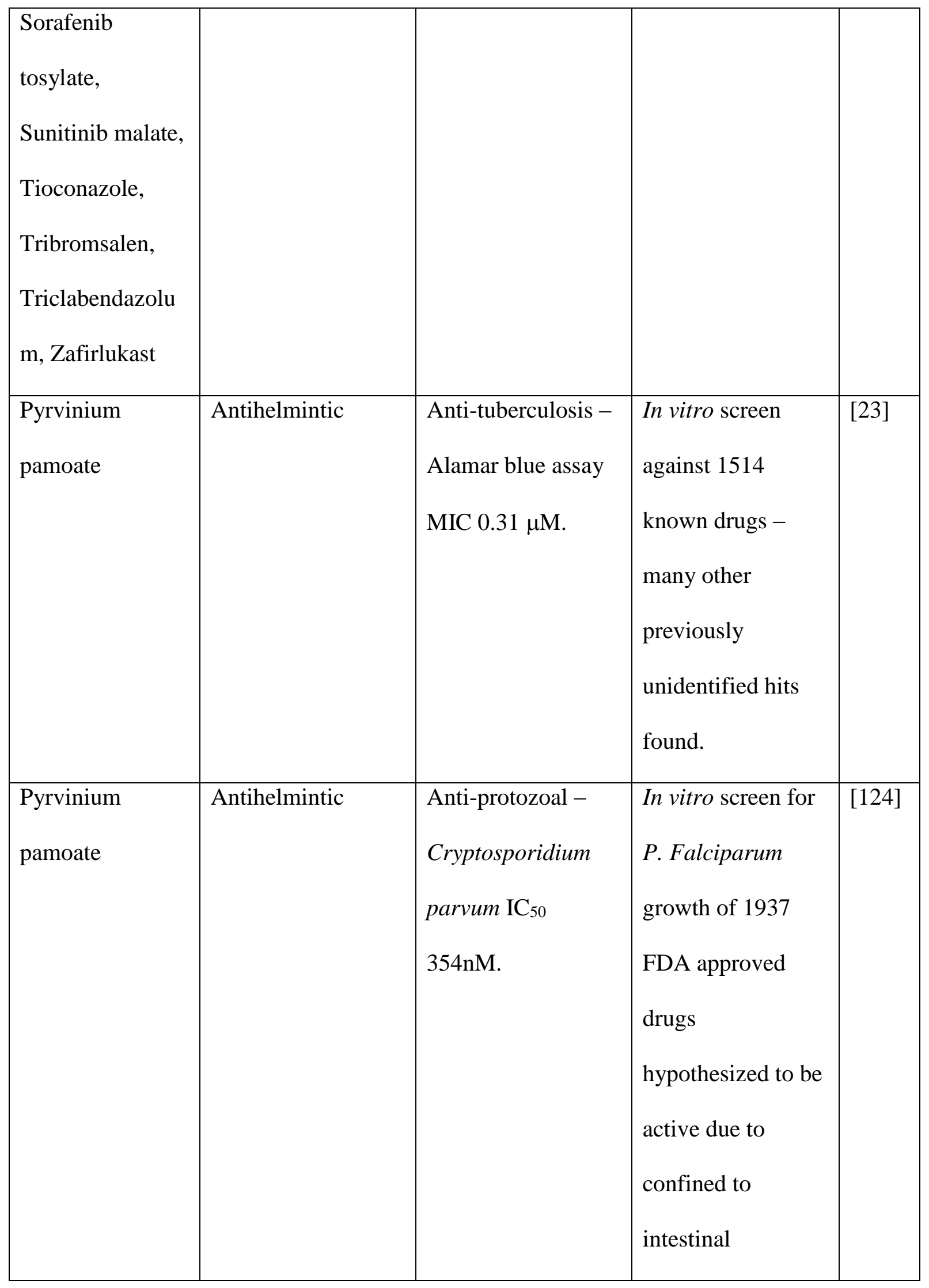




\begin{tabular}{|c|c|c|c|c|}
\hline & & & epithelium. & \\
\hline $\begin{array}{l}\text { Pyrvinium } \\
\text { pamoate }\end{array}$ & Antihelmintic & $\begin{array}{l}\text { Anti-protozoal - } \\
\text { against } T \text { Brucei } \\
\mathrm{IC}_{50} 3 \mu \mathrm{M} \text {. }\end{array}$ & $\begin{array}{l}\text { Screened } 2160 \\
\text { FDA approved } \\
\text { drugs and natural } \\
\text { products from } \\
\text { Microsource. } 15 \\
\text { other drugs active } \\
\mathrm{IC}_{50} 0.2-3 \mu \mathrm{M}\end{array}$ & [125] \\
\hline Riluzole & $\begin{array}{l}\text { Amyotrophic } \\
\text { Lateral Sclerosis - } \\
\text { inhibits glutamate } \\
\text { release and } \\
\text { reuptake }\end{array}$ & 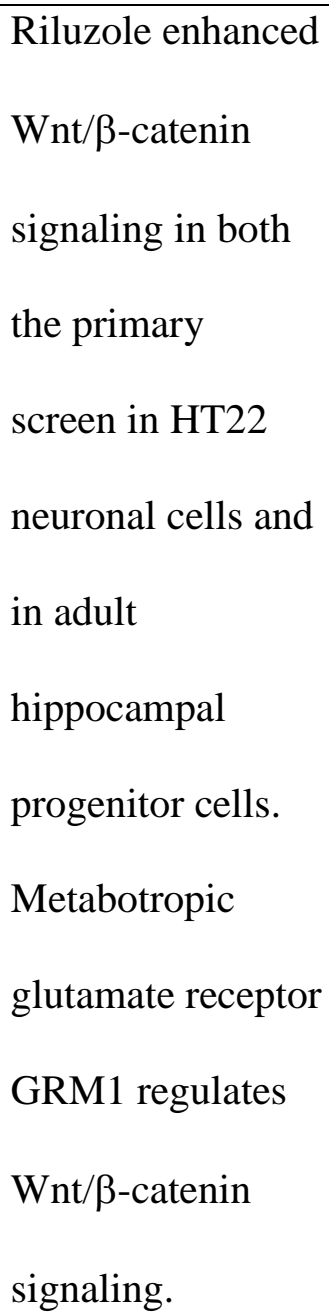 & $\begin{array}{l}\text { Screened } 1857 \\
\text { compounds (1500 } \\
\text { unique) in vitro } \\
\text { treating melanoma } \\
\text { cells with riluzole } \\
\text { in vitro enhances } \\
\text { the ability of } \\
\text { WNT3A to } \\
\text { regulate gene } \\
\text { expression. }\end{array}$ & [126] \\
\hline Closantel & A veterinary & Onchocerciasis, or & Screened 1514 & [127] \\
\hline
\end{tabular}




\begin{tabular}{|c|c|c|c|c|}
\hline & $\begin{array}{l}\text { anthelmintic with } \\
\text { known proton } \\
\text { ionophore activities }\end{array}$ & $\begin{array}{l}\text { river blindness } \mathrm{IC}_{50} \\
1.6 \mu \mathrm{M} \text { competitive } \\
\text { inhibition constant } \\
\left(\mathrm{K}_{\mathrm{i}}\right) \text { of } 468 \mathrm{nM} \text {. }\end{array}$ & $\begin{array}{l}\text { FDA approved } \\
\text { drugs (JHCCL) } \\
\text { against the } \\
\text { chitinase OvCHT1 } \\
\text { from O. volvulus. }\end{array}$ & \\
\hline Nitroxoline & $\begin{array}{l}\text { Antibiotic used } \\
\text { outside USA for } \\
\text { urinary tract } \\
\text { infections. }\end{array}$ & $\begin{array}{l}\text { Antiangiogenic } \\
\text { agent inhibits Type } \\
2 \text { methionine } \\
\text { aminopeptidase } \\
\text { (MetAP2) IC } 50 \\
54.8 \mathrm{nM} \text { and } \\
\text { HUVEC } \\
\text { proliferation. Also } \\
\text { inhibits Sirtuin } 1 \\
\text { IC } 5020.2 \mu \mathrm{M} \text { and } \\
\text { Sirtuin } 2 \mathrm{IC}_{50} 15.5 \\
\mu \mathrm{M} .\end{array}$ & $\begin{array}{l}\text { Screened } 2687 \\
\text { FDA approved } \\
\text { drugs (JHCCL) } \\
\text { for inhibition of } \\
\text { HUVEC cells. } \\
\text { Also found the } \\
\text { same compound in } \\
\text { HTS of } 175,000 \\
\text { compounds } \\
\text { screened against } \\
\text { MetAP2. Also } \\
\text { active in mouse } \\
\text { and human tumor } \\
\text { growth models. }\end{array}$ & [128] \\
\hline Glafenine & Analgesic & $\begin{array}{l}\text { Inhibits ABCG2 } \\
\mathrm{IC}_{50} 3.2 \mu \mathrm{M} \text { could } \\
\text { be used with } \\
\text { chemotherapeutic }\end{array}$ & $\begin{array}{l}\text { Screened FDA } \\
\text { approved drugs } \\
\text { (JHCCL) with } \\
\text { bioluminescence }\end{array}$ & [129] \\
\hline
\end{tabular}




\begin{tabular}{|c|c|c|c|c|}
\hline & & $\begin{array}{l}\text { agents to counteract } \\
\text { tumor resistance. }\end{array}$ & $\begin{array}{l}\text { imaging HTS } \\
\text { assay. Discovered } \\
37 \text { previously } \\
\text { unknown ABCG2 } \\
\text { inhibitors. }\end{array}$ & \\
\hline Tiagabine & $\begin{array}{l}\text { Antiepileptic } \\
\text { (enhances gamma- } \\
\text { aminobutyric acid } \\
\text { activity). }\end{array}$ & $\begin{array}{l}\text { Neuroprotective in } \\
\text { N171-82Q and } \\
\text { R6/2 mouse models } \\
\text { of Huntington's } \\
\text { disease (HD). }\end{array}$ & $\begin{array}{l}\text { Initial screen of } \\
\text { NINDS } \\
\text { Microsource } \\
\text { database of drugs } \\
\text { (1040 molecules) } \\
\text { against PC12 cell } \\
\text { model of HD } \\
\text { found nepecotic } \\
\text { acid which is } \\
\text { related to } \\
\text { tiagabine. }\end{array}$ & [130] \\
\hline $\begin{array}{l}\text { Digoxin, Oubain, } \\
\text { Proscillardin A }\end{array}$ & $\begin{array}{l}\text { Cardiac glycosides } \\
\text { used to treat } \\
\text { congestive heart } \\
\text { failure and } \\
\text { arrthymia. }\end{array}$ & $\begin{array}{l}\text { Anticancer - } \\
\text { Inhibition of } \\
\text { hypoxia-inducible } \\
\text { factor } 1 \mathrm{IC}_{50}<400 \\
\mathrm{nM}\end{array}$ & $\begin{array}{l}\text { Screened } 3120 \\
\text { FDA approved } \\
\text { drugs (JHCCL) } \\
\text { screened against } \\
\text { reporter cell line } \\
\text { Hep3B-c1. } \\
\text { Digoxin also tested }\end{array}$ & [131] \\
\hline
\end{tabular}




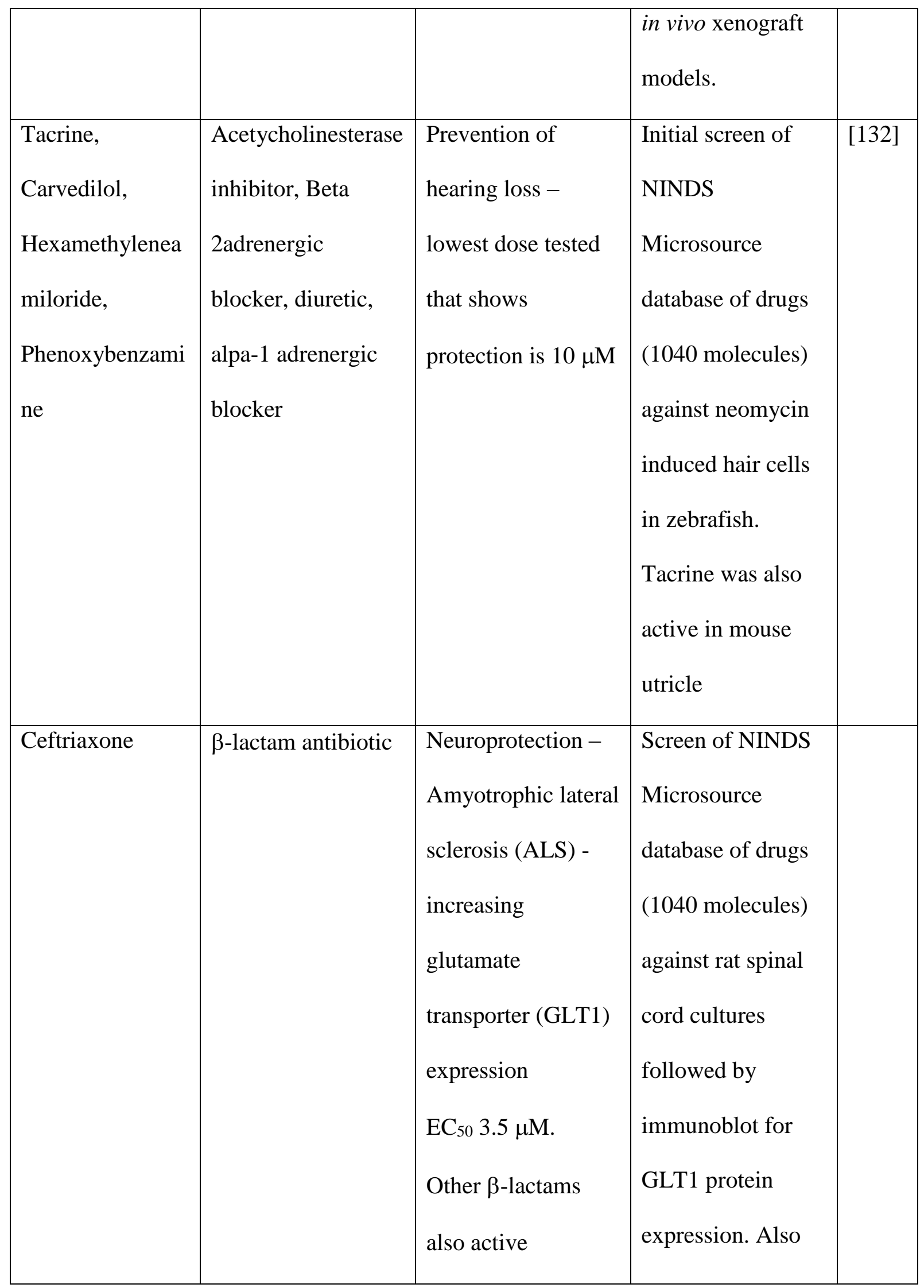




\begin{tabular}{|c|c|c|c|c|}
\hline & & & $\begin{array}{l}\text { tested in ALS } \\
\text { mouse model, } \\
\text { delaying neuron } \\
\text { loss, increased } \\
\text { survival. }\end{array}$ & \\
\hline Flufenamic acid & $\begin{array}{l}\text { Non steroidal anti- } \\
\text { inflammatory drug }\end{array}$ & $\begin{array}{l}\text { Familial amyloid } \\
\text { polyneuropathy - } \\
\text { Inhibits } \\
\text { transthyretin. }\end{array}$ & $\begin{array}{l}\text { Screening library } \\
\text { not described. }\end{array}$ & [133] \\
\hline
\end{tabular}


Table 3. FDA approved compounds found to inhibit transporters by in silico-in vitro approach. Additional examples of transporter pharmacophore searches can be found in a recent review [134].

\begin{tabular}{|c|c|c|c|c|}
\hline Compounds & Transporter & Biological effect & $\begin{array}{l}\text { Pharmacophore } \\
\text { features }\end{array}$ & reference \\
\hline $\begin{array}{l}\text { Aspartame } \\
\text { Fluvastatin, } \\
\text { Repaglinide, }\end{array}$ & hPEPT1 & $\begin{array}{l}\text { Inhibit uptake of } \\
\text { natural substrates, } \\
\text { other drug that are } \\
\text { substrates. }\end{array}$ & $\begin{array}{l}2 \text { Hydrophobic, } \\
\text { one hydrogen } \\
\text { bond acceptor, } \\
\text { one hydrogen } \\
\text { bond donor, one } \\
\text { negative } \\
\text { ionizable feature }\end{array}$ & [32] \\
\hline $\begin{array}{l}\text { Acitretin, } \\
\text { Cholecalciferol, } \\
\text { Misoprostol, } \\
\text { Nafcillin, } \\
\text { Repaglinide, } \\
\text { Salmeterol, } \\
\text { Telmisartan }\end{array}$ & P-gp & $\begin{array}{l}\text { Decrease clearance } \\
\text { of drugs by } \\
\text { inhibiting efflux } \\
\text { into intestine of P- } \\
\text { gp substrates. }\end{array}$ & $\begin{array}{l}3 \text { Hydrophobic } \\
\text { features and } 2 \\
\text { hydrogen bond } \\
\text { acceptor features }\end{array}$ & [33] \\
\hline $\begin{array}{l}\text { Thioridazine, } \\
\text { Vinblastine, }\end{array}$ & OCTN2 & $\begin{array}{l}\text { Inhibition may } \\
\text { cause }\end{array}$ & $\begin{array}{l}3 \text { Hydrophobic } \\
\text { features and } 1\end{array}$ & [35] \\
\hline
\end{tabular}




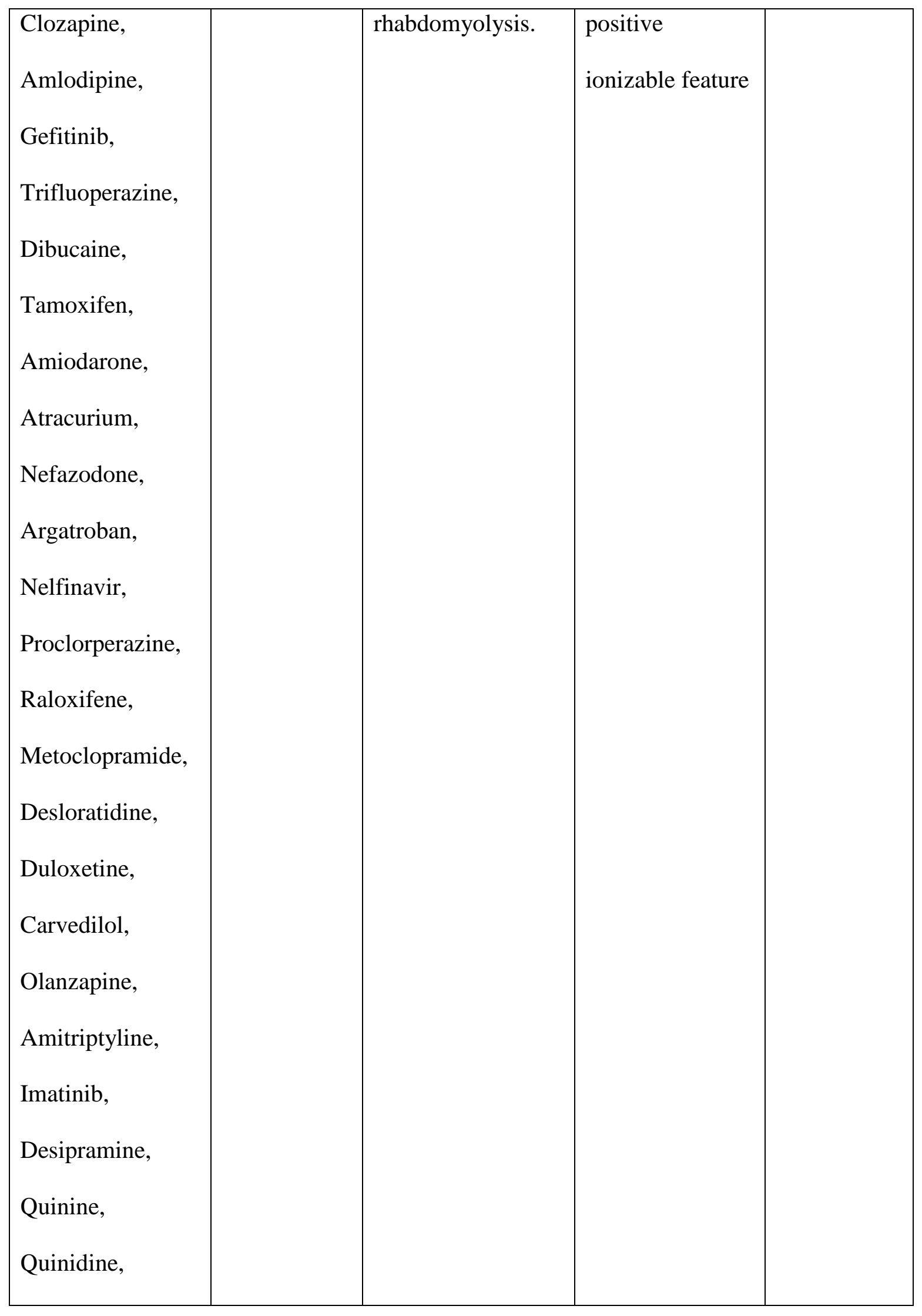




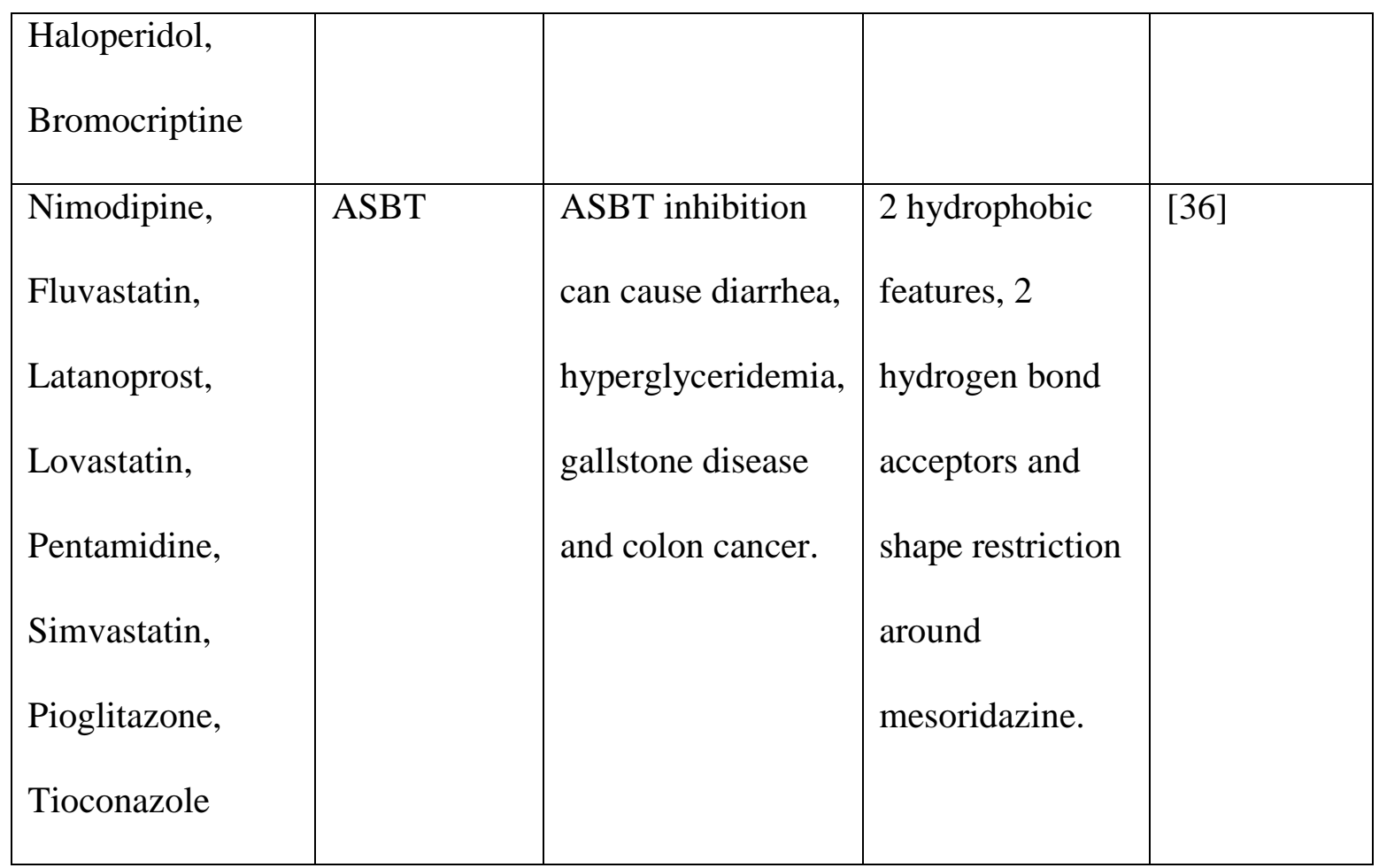


Table 4. A subset of the $>20$ CDD publicly available antimalarial and tuberculosis

(TB) data sets.

\begin{tabular}{|c|c|c|}
\hline Database Name/Source & Description & Molecules \\
\hline U.S. Army Survey & $\begin{array}{l}\text { An extensive collection of antimalarial drug animal SAR } \\
\text { data, including structures, bioactivity etc, published } \\
\text { originally by the U.S. Army in } 1946 \text {. }\end{array}$ & 12,318 \\
\hline St Jude Childrens & Supplemental data for Nature Article [135]- structures & 1524 \\
\hline Research Hospital & $\begin{array}{l}\text { tested in a primary screen, with additional data in eight } \\
\text { protocols: Bland-Altman analysis, calculated ADMET } \\
\text { properties, Phylochemogenetic screen, Sensitivity, Synergy, } \\
\text { and Enzyme Assays, as well as a Thermal Melt Analysis. }\end{array}$ & \\
\hline Novartis Malaria & $\begin{array}{l}\text { Data from Nature paper [136] Plasmodium falciparum } \\
\text { strains 3d7 (drug-susceptible) and W2 (chloroquine-, } \\
\text { quinine-, pyrimethamine-, cycloguanil-, and sulfadoxine- } \\
\text { resistant), obtained from MR4, were tested in an } \\
\text { erythrocyte-based infection assay for susceptibility to } \\
\text { inhibition of proliferation by selected compounds }\end{array}$ & 5695 \\
\hline Johns Hopkins- Sullivan & Percent inhibition of approved drugs at $10 \mu \mathrm{M}$ & 2693 \\
\hline MLSMR & $\begin{array}{l}\text { A diverse collection tested by the Southern Research } \\
\text { Institute against Mtb H37Rv. The most active compounds } \\
\text { have dose response and cytotoxicity data. }\end{array}$ & 214,507 \\
\hline TB efficacy data from & TB Efficacy Data from over 300 published literature & 6,771 \\
\hline
\end{tabular}


the literature

sources. Data includes PubMed citations, targets, cells and

organisms testes, $\mathrm{MIC}, \%$ Inhibition, $\mathrm{EC}_{50}, \mathrm{IC}_{50}$, etc.

TAACF- NIAID-CB2 Results of screening a commercial compound library by the

Southern Research Institute to inhibit the growth of M.

tuberculosis strain H37Rv.

Novartis Mtb
Aerobic and Anaerobic hits 


\section{LEGEND TO FIGURES}

Figure 1. A. Cetirizine. B.Cetirizine mapped to a Catalyst common features pharmacophore based on 3 actives and 2 inactives for OCTN2 [35]. The pharmacophore contains 2 hydrophobic features (cyan) and a positive ionizable feature (red). C. Cetirizine mapping to a Catalyst pharmacophore derived from 22 drugs with $\mathrm{K}_{\mathrm{i}}$ data for OCTN2 (observed and predicted data described in Diao et al., [34]). The pharmacophore contains 2 hydrophobic features (cyan), a hydrogen bond acceptor (green) and a positive ionizable feature (red).

Figure 2. Receiver operator characteristic plot for the FDA approved Mtb hits $(\mathrm{N}=21)$ used as a test set $(\mathrm{N}=2108)$ for a previously published Bayesian model [95]. Purple $=$ best rate of finding hits, Yellow $=$ Bayesian model, Blue $=$ random rate of finding hits .

Figure 3. A repositioning strategy using the CDD (see:

http://www.collaborativedrug.com/register), ChemSpider (www.chemspider.com) or other databases (bioactivity data for target or disease of interest and FDA drug dataset) in combination with computational methods (pharmacophore, similarity assessment, machine learning etc). 